\title{
From English-Only to Multilingualism: English in the Language Policy of the United States
}

\author{
Danping Wang ${ }^{1}$ \\ ${ }^{1}$ Department of General Education, Technological and Higher Education Insitute of Hong Kong, Hong Kong, China \\ Correspondence: Danping Wang, School of Languages and General Education, Technological and Higher Education \\ Insitute of Hong Kong, 20A Tsing Yi Road, Tsing Yi, N.T. Hong Kong. Tel: 852-2176-1827. E-mail: \\ dpwang@vtc.edu.hk
}

Received: September 6, $2015 \quad$ Accepted: September 18, 2015 Online Published: October 12, 2015

doi:10.5430/ijelt.v3n1p32 URL: http://dx.doi.org/10.5430/ijelt.v3n1p32

\begin{abstract}
Focusing on English, this paper presents a critical review of the long-standing controversial education language policies and language movements in the United States. This paper seeks to provide an in-depth perception of the history of English in courtse of national development of the United States which helps interpret today's English-only monolingualism in ESL classrooms. Through the analysis of the major disputes of whether to have English as the official language of the country, this study has offered detailed accounts of the process of language policy planning during the years of "English Officialization", "Bilingual Education" and "English Plus". The study hopes to shed some light on understanding how to create, sustain, or reduce a language policy in education while also presenting the struggles in the areas for political and economic participation, democracy, and human rights. This study also attmpts to analyse complexities of the debates of eduation language policies and the theoretical breakthroughs in foreign language teaching that could create a justifiable space for multilingual learners to learn through their mother tongues. The paper argues that the monolingual approach for Enlgish language learning should be rejected because it denies students the right to draw on their language resources according to the sociocultural theory in language learning. Further recommendations to language policy planning are provided for further promoting the multiculturalist perspective, and pedagogical suggestions were also provided for ESL teachers to rethink about classroom language use.
\end{abstract}

Keywords: language policy, policy planning, English-only, bilingual education, multilingualism

\section{Introduction}

It is commonsensical for many people that English is the common language in the United States. Yet, it is suprising for people to find that English has never been made the official language by legisture. Much has been said about the global spread of English and its profound impact on language policy planning in many countries (Nunan, 2003; Kirkpatrick, 2008; Phillipson, 2003), which has directly and long-term influence on the development of English language education programmes from kindergarten to university levels. Equally important, it is of research and policy importance to examine the policy planning of English in one of the most multilingual countries in the world. The purpose of this study is to inform English language educators that language education policy is highly complex, involving multiple interests and conflicts, and superdiversity in language classroom is a trend that cannot be halted.

At the beginning of the 21st century, one hears recurrent concerns about the official status of English in the U.S. and, simultaneously, about the preservation of languages other than English (Wiley, 2004, 319). For a long time in the United States, this struggle has centred on moves to make English the nation's official language and to marginalise bilingual education in public schools, though it is clear to all that America is an immigrant country. Language education policies continue to be hotly debated, and schools, especially, have become "a battleground over Americanization". Debates over whether or not English should be the official language tends to be narrowly focused on non-linguistic factors and largely on the opinions and motives of supporters and opponents (Crawford, 1992, 171). As a result, the more substantive linguistic matters tend to be neglected and the multilingual reality has become a fact that is troubling the country's overall education development. The controversy is exerting a strong influence on policymakers - which makes public education on this topic crucial. 
United States is one of the most linguistically and culturally diverse countries in the world. At the end of the $20^{\text {th }}$ century, "people of colour made up $28 \%$ of the nation's population, and this number will grow to $38 \%$ in 2024 and $47 \%$ in 2050 according to the U.S. Bureau of the Census" (Banks, 2001, ix). Up to date, approximately 380 languages are spoken by U.S. residents according to the Census Bureau (Shin \& Bruno, 2003), and they represent the "new immigrants" which has reshaped the linguistic environment of the country. Unlike earlier waves of immigrations, which originated in Europe and were largely white, these "new immigrants" come primarily from Latin America, Southeast Asia, and the Caribbean, who have brought an array of different langauges, cultures, religions, traditions and ways of thinking to classrooms and socieities. The demographic shift and the increasing multilingualism is having a profound impact on U.S. schools.

Nevertheless, the monolingual approach remains the most prevailing and overarching education language policy dominating classrooms all over the world, particularly in language classrooms. This monolingual paradigm has largely shaped mainstream foreign language classroom practice for many decades and has successfully convinced several generations of school leaders, teachers, parents and students that learning monolingually is the best practice (Crawford, 1991). However, this kind of "pedagogical immersion ideology" (Lin, 2015) may inhibit students' ability to draw on their own language resources and strengths in learning a new language. It is crucial to reiterate that the ability to build the new on the foundation of the known is the direction in which modern and constructive language education is heading (Butzkamm, 2003). More importantly, the monolingual English education policy could exacerbate the learning opportunities of migrant pupils and all non-native English speakers in pursuing academic and professional success. To this end, this study hopes to shed some light of the complexities of the debates of eduation language policies and the theoretical breakthroughs in foreign language teaching that could create a justifiable space for multilingual learners to learn through their mother tongues.

\section{Language Policy Planning}

Language conflicts generally incorporate symbolic struggles over cultural, religious, ethnic, or national identity. Yet they represent more than contending philosophies of assimilation and pluralism, disagreements about the rights and responsibilities of citizens, or debates over the true meaning of 'Americanism' (Crawford, 2000). Ultimately language policies are determined by fights for social and economic supremacy, which are always under the surface of the public debate. McCarty (2004) pointed out "as the most powerful country in the world in which English dominates as the national if not the official language, debates over the status and role of English have shaped educational practices for centuries" (p.73). Before examining the language policies, a brief review of language planning and policy formation may be helpful in understanding the current debates over language policy in the States.

Among many definitions, this is one of the most explicit one. Language planning refers to "deliberate efforts to influence the behaviour of others with respect to the acquisition, structure, or functional allocation of their language codes" (Cooper, 1989, 45; Heath, 1992, 21). It is also important to remember what Pennycook (2001) states, "when we fight in support of a community-based language program, when we allow or disallow the use of one language or another in our classrooms, when we choose which language to use in Congress, conversations, conferences, or curricular, we are making language policy" (p. 25). Language policy, therefore, is not only found in public and official acts and documents, it is also found in simple, every day speech. The issue is also seen as an indicator of leaders who desire to change society through educational reforms. In a sense, it implies scepticism about the efficacy of "natural" forces that aims at "change" by means of rationally coordinated state actions (Weinstein, 1983, 37).

The topic of language policies in the U.S. is often associated with the saying "government action or lack of it" (Ricento \& Burnaby 1998, 33). The government has taken the form of action in addressing the issue as one that did not need any polices- or any other action for that matter. Its standard policy was to have no policy on language that would explicitly define an official national language, and has been this way since the establishment of the United States. There are several possible reasons that the founders of the U.S. chose not to designate English as the official language:

(1) The dominance of English was self-evident, rendering an official policy unnecessary; (2) The founders respected linguistic diversity and minority rights when U.S. was aiming at attracting more immigrants to settle down; (3) Hesitant to offend minorities who had supported the revolutionary cause, the founders opted for a tolerant approach (Wiley, 2004, 320).

Regardless of the original thinking of the founders, English has functioned as if it was the official language 
throughout the history of the U.S., and it has often been designated as official for specific purposes. Thus, English has generally possessed the status of the official language, and this is functionally more important than its official designation. This point seems to be missed by many who support official English policies. When examining the policies aiming for children's future, one must ask whether that is exactly what those policies are intended to do and consequences regarding learning outcomes and social justices.

Official English legislation is therefore considered "bad for civil rights, bad for America's interests, and even bad for English". James Crawford, the director of the Institute for Language and Education Policy of U.S., gave this testimony before the House Subcommittee on Education Reform, and questioned "our nation has gotten by far more than 200 years without adopting an official language. Why do we need one now?" (Crawford, 2006, 2) Nevertheless, losing the place as the official language in legislature, English has remained the most powerful language and the most desirable language in the classrooms since Amrican was founded. In the following section, I will give more detailed accounts on the education language planning and policy in the U.S., which I hope could offer some insights for policy-making in multilingual countries and language education development in multilingual classrooms elsewhere.

\section{English Policy in the United States}

Eearly in 1907, Roosevel has explicitly argued for the official status of English in the U.S. when he introduced his idea on immigrants and being an American. He said "We have room for, but one flag. We have room for, but one language here. And that is the English language." Roosevelt $(1992,85)$ further explained that "We must have but one language. That must be the language of the Declaration of Independence. We cannot tolerate any attempt to oppose or supplant the language and culture that has come down to us. Any force which attempts to retard that assimilative process is a force hostile to the highest interests of our country. "English is always considered as the glue that unites the States. As Schlesinger (1992) said English, as a common language, is an essential bond of cohesion in such a heterogeneous nation like America (p. 115). Considering the survival and social networking in the U.S., obviously all American citizens including immigrants should know English and speak English. Therefore, it is common to hear teachers comment that "when we succeed in helping our students use the majority language fluently, we are empowering our students rather than depriving them" (Miller, 1998, 179). The challenge of Americanization is not to stamp out foreign language, but to guarantee that all Americans, native and foreign-born, can engage themselves in the common language of their democracy.

However, language diversity is a fact of life throughout the world and the superdiversity of modern cities have made it imperative to examine the language policy and language use in societies and classrooms. This has been equally true in the United States, where hundreds of immigrant and indigenous tongues have coexisted with English. As a marker of ethnic differences, language sometimes plays a role in ethnic conflicts. But diverse societies need not be divided societies. In a study of 130 nation-states, the sociolinguist (Fishman, 1991, 5) found no correlation between linguistic diversity and civil strife. For example, in Switzerland, four language groups have coexisted harmoniously for centuries, enjoying equal rights under their constitution, and students have rights to choose which language to study first, and which language they want to learn thereafter. Languages are in diversity but never at a war. In the following three parts, I will discuss the rise and fall of the most important language policies in the U.S.

\subsection{English Officialization}

Einar Haugen (1972) pointed out that "America's profusion of tongues has made her a modern Babel, but a Babel in reverse". Although English as long been the dominant language in the United States, it has never legally been declared as the official language. Interestingly, as Tottie (2002) argued "neither the Declaration of Independence nor the Constitute makes any mention of it: they were both written in English as a matter of course" (p. 240). However, in 1981, Senator Hayakawa from California, a Japanese-American language scholar, proposed a constitutional amendment to make English the official language of the United States. It sparked a debate that is still going on, though it failed to be accepted by the Senate. None of Official English bills since then has been approved, but they are all actively working at the national level. English-Only supporters have taken their message and their dollars to the state levels to attempt to make English official. Finally, California, the state with the fastest growing "minority majority", declared English the state's official language with considerable financial support in 1986 (McCarty, 2004, 85). Following this, a number of states have adopted various forms of Official English legislation. Subtracting Hawaii (which is officially bilingual) and Alaska (whose English-only initiative has been declared unconstitutional) leaves a total of 27 states with active Official English laws (Crawford, 2008b). Table 1 shows the year and the states of Official English laws. 
Table 1. The Year and the States of Official English Laws (Alphabetical order)

\begin{tabular}{||l|l||l|l||l|l||l|l||l|l||}
\hline Alabama & 1990 & Florida & 1988 & Indiana & 1984 & Nebraska & 1923 & South Dakota & 1995 \\
\hline Alaska & 1998 & Georgia & 1996 & Kansas & 2007 & New Hampshire & 1995 & Tennessee & 1984 \\
\hline Arizona & 2006 & Hawai'i & 1978 & Kentucky & 1984 & North Carolina & 1987 & Utah & 2000 \\
\hline Arkansas & 1987 & Idaho & 2007 & Mississippi & 1987 & North Dakota & 1987 & Virginia & 1981 \\
\hline California & 1986 & Iowa & 2002 & Missouri & 1998 & Oklahoma & 2010 & Wyoming & 1996 \\
\hline Colorado & 1988 & Illinois & 1969 & Montana & 1995 & South Carolina & 1987 & & \\
\hline
\end{tabular}

Notably, a mainstream idea is not necessarily a rational one, free of prejudice and paranoia. The campaign to 'officialize' English in the United States rests on the claim that the most successful and dominant world language in history is under siege in its strongest bastion. In this decades-long debate, factual support has generally proved unnecessary for English-Only proponents to advance their cause. The facts are that, except in isolated locales, immigrants to the United States have typically lost their native languages by the third generation (Tottie, 2004, 233). It is no wonder that many scholars say that the least diverse period is coming, linguistically speaking, in American history. Demographic data from a variety of sources indicate that today's immigrants are acquiring English more rapidly than ever before (Crawford, 2008a). It also implies that it is language other than English that are threatened in the United States today. Without the replenishing effects of immigration, most other languages would soon die out.

Frequently, on first hearing about the Official English issue, monolingual Americans fail to see the downside. Many wonder, since English is so dominant in this country, whether it isn't already the official language. And if not, why not? This reaction is not surprising since - compared with citizens of many other nations - Americans have limited experience with the politics of language. But when the potential impact of Official English is explained, support drops off sharply (Language Policy Website, 1997). Favoring English as the official language, in itself, should not be equated with racism. Yet, racist attitude toward Latinos in particular have been closely associated with this movement. U.S. English, the first and largest English-Only group established by Hayakawa and John Tanton, was a spinoff from the immigration-restriction lobby. John Tanton was forced to resign in 1988, after he wrote a memo containing vicious anti-Hispanic stereotypes. Among other things, Tanton wrote:

"Gobernar es poblar" translates "to govern is to populate." In this society where the majority rules, does this hold? Will the present majority peaceably hand over its political power to a group that is simply more fertile? Perhaps this is the first instance in which those with their pants up are going to get caught by those with their pants down! (Crawford, 2000, 23)

The same year an internal survey (Gary C. Lawrence Co., 1992) commissioned by U.S. English found that revealed their ultimate purpose for supporting this group in an astonishingly racist perspective. When asked why they had joined the organization, $42 \%$ of its members agreed with the statement: "I wanted America to stand strong and not cave in to Hispanic who shouldn't be here!"

\subsection{Bilingual Education}

The motto on the U.S. Seal writes "E pluribus unum", which is the Latin for "Out of Many, One". The developments of the English Officialization Movements are situated in the emergence of the English-Only Movement of the 1980s and its achievements, including the successful abolishment of the Bilingual Education Act. The English-Only movement contextualizes an ideology of English monolingualism in the U.S.. Meanwhile, education mandate in bilingualism in the U.S. has its own problems.

American's bilingual education is a classic example of an experiment that began with the best of humanitarian intentions but has turned out to be terribly wrongheaded. The Bilingual Education Act was a modestly funded (\$7.5 million for the first year in 1968) but in the end, it could not keep any language alive. Ralph Yarborough, the Senator of Texas, explained, "It is not the purpose of the bill to create pockets of different languages through the country, but just to try to make those children fully literate in English" (Cruz 1998, 29). The accumulated research of the past thirty years reveals almost no justification for teaching children in their native languages to help them learn either English or other subjects. The presumed purpose of bilingual education is transitional: to move non-English-speaking children as quickly as possible from bilingual into all-English classes (Schlesinger, 1992, 113). However, some teachers find that it encourages concentrations of Hispanics to stay together and not be integrated," says Alfredo Mathew, a Hispanic civic leader (Porter, 1996, 113). There is no wonder why Latino parents reject the program 
designed for the benefit of their children. They firmly believe that using some language other than English dooms people to second-class citizenship in American society (Cruz, 1998, 28).

The first step on abolishing Bilingual Education Act was the 1996 confrontation at the Ninth Street School in Los Angeles. According to news accounts, provided by the University of California, Los Angeles (Hispanic Links News Services 1998), immigrant parents were so frustrated with a mostly Spanish curriculum and an unresponsive bureaucracy that they pulled their children out of school to demand English instruction. Two years later, while people were still hearing about the Ninth Street boycott, it has been featured in countless news stories. What emerged from this was Proposition 227, the campaign to "eliminate bilingual education in California by June 1998". In 1998, there was a ballot initiative on Proposition 227, the second but most crucial step to abolish bilingual education. The proposition was the result of an initiative by the computer industry entrepreneur, Ron Unz, who considered bilingual education to be a waste of public money, and funded for Proposition 227. This proposition won by a large majority. Students now have to take part in an "English immersion program" for up to one year and then take all their subjects in English. Two years later, newspapers reported that the abolition of bilingual education was a success as far as English proficiency is concerned (Tottie, 2002, 244). Miller's (1998) book, "The Unmaking of Americans: How multiculturalism has undermined the assimilation ethic", unveiled the reason why the motto on the United States Seal is "E pluribus unum". He writes, "The United States used to be quite good at making Americans. Today, when we are at our worst, we are unmaking them." (Miller, 1998, ix) The crisis chiefly derives from the fact that schools have lost their faith in Americanization, but spent all their time on the bilingual education. This is a mistake, since so much of success that immigrant children will have in life depends on how well they learn English in schools (Miller, 1998 175). Education is important for everybody, but for immigrant kids, it takes on special meaning because they have so much to learn. They need to develop English language skills as quickly as possible and are expected to perform academically as well as their native English-speaking peers. This is partly because elementary students are at a perfect age for gaining another language with relative ease (Miller, 1998, 176). Nobody has given them any breaks for being immigrants.

When President Ronald Reagan took place, Carter's Administration proposal on bilingual education was soon denounced as against the nation's development and completely wrong. On October 10, 1981, New York Times pointed out that mother tongue teaching was, in fact, "creating barriers for them instead of helping them preserve their ethnic identity. Immersion would be the only correct way to learn English." (Dicker, 1996, 145) Due to the dramatic shift of government and public attitude, bilingual education saw its dooms day while the ideology of monolingualism took the dominance, as it did a century ago. Monolingualism also pointed out that "bilingual education actually means monolingual SPANISH-ONLY (caps in original) for the first 4 to 7 years of school" (Fillmore, 2004, 355). It is considered to have "failed to teach children to read and write in English; children are not being moved into mainstream classes fast enough; Latino children receive the lowest test scores and have the highest drop-out rates of any immigrant group despite bilingual education; there are 140 languages spoken by immigrants students in California schools - how are all of these languages to be accommodated?" (Fillmore, 2004, 355) Many theoretical and technical problems need to be carefully addressed in order to truly promote multilingualism.

\subsection{English Plus}

When a new school reform measure known as No Child Left Behind (NCLB) was proposed by the Bush administration in 2002, the Bilingual Education Act finally expired quietly, finishing its 34 years of obligation on promoting equal access to the curriculum, training a generation of educators. The funding under NCLB Act - \$669 million in 2006 - is currently based on "self-reported" census data about English proficiency rather than on objective assessments by school personnel (Crawford, 2007). To date, over a decade after passage of the NCLB Act, it is clear that the law is failing English language learners. Its one-size-fit-all approach ignores what is unique about English language learners, contradicting the basic principles established by U.S. Supreme Court. In practice, NCLB has resulted in a two-tier educational system, in which English language learners are taught at a substandard curriculum that stresses basic skills, while more privileged students receive a challenging, all-round education that encourages the critical thinking needed in college and professional careers.

NCLB has established a top-down, prescriptive, arbitrary, inequitable, and punitive system that blames under-achievement on educators alone while ignoring the effects of poverty, funding disparities, racial segregation, and other non-school factors known to have a major impact on educational attainment. Consequently, there are more and more proposals suggesting a possible re-authorizing of the NCLB Act. Crawford and MacSwan (2008), from Institute for Language and Education Policy, made a statement for Barack Obama's transition team on December 15, 2008. They summarized that "data from the National Assessment of Education Progress show that English language 
learners have made little or no appreciable gains under the NCLB Act." It has provided recommendation to the NCLB, along with many other proposals (Crawford \& MacSwan 2008, 1; Crawford, 2008c, 137). However, what Obama's interested is a more ambitious education agenda, besides a vow to "reform NCLB". In a CNN-sponsored debate in Texas, Mr. Obama said:

One of the failures of No Child Left Behind, a law that I think a lot of local and state officials have been troubled by, is that it is so narrowly focused on standardized tests that it has pushed out a lot of important learning that needs to take place. And foreign languages are one of those areas that I think has been neglected. I want to put more resources into it. (Democratic candidates' debate, February 21, 2008, Austin, TX)

Barack Obama's historic victory and Democratic gains in Congress have transformed the political environment in ways that will make many things possible. Educators can now hope for changes that we could only dream about during the past eight years. However, the very first news they heard from him was about adding one more language to the official language in the U.S. Obama addressed the issue of official languages on July 9, 2008 by endorsing one: Spanish. Instead of worrying about immigrants learning English, he told an audience, America should be teaching its children Spanish. Mr Obama explains:

I agree that immigrants should learn English. But instead of worrying about whether immigrants can learn English - they'll learn English - you need to make sure your child can speak Spanish. You should be thinking about how can your child become bilingual? We should have every child speaking more than one language. (Town Hall Meeting, Powder Springs, GA, July 8, 2008)

If your answer to, "Do you understand Spanish?" is no, get ready to be left behind. With the astonishing surge over the last decade in the Hispanic population in the United States, speaking more than one language is becoming more of a necessity than a choice in many parts of the country. Americans are scrambling to learn a language now spoken by many of the 35.3 million Hispanics in the United States (McArthur, 2003, 200). However, we agree that every child should know more than one language, but it doesn't have to be Spanish. What America truly needs is English plus X, not English plus One. As a result, New Mexicao (1989), Oregon (1989), and Washington State (1989) endorsed the "English Plus" Resolution in order to support the language rights in the country. Further, as a counterstatemtment to the English-Only moment, the National Langauge Policy was published in 1988 to encourage all U.S. citizens to learn foreign langauges. However, the English-Only ideology has profoundly penetrated every corner of the society, which would require a lot of efforts to promote a multiculturalist perspective.

Strickly speaking, United States has never had a clear cut language policy, consciously planned or national in scope. It has had language policies that were mostly ad hoc responses to immediate needs or political pressure, often contradictory or inadequate to cope with changing times (Crawford, 2008a, 11). On one hand, the United States needs a language policy that reflects the values of ethnic tolerance, respect for civil rights, and generosity in meeting social needs. On the other hand, it is urgently desirable to have a well-thought language policy that could offer some policy guidance for schools to manage their increasing multilingual classrooms.

\section{Teaching English in Multilingual Classrooms}

Teaching approaches are often determined by political rather than pedagogical factors. The question of whether or not to support the students' use of their mother tongue is not simply an educational or pedagogical matter. Historically, assumptions about L1 use in the L2 class are traceable mostly to the "Great Reform" of the late 19th century (Hawkins, 1987, 404). Cook (2001) argued that these assumptions have affected many generations of foreign language teachers and students, and are taken for granted as the foundation of language teaching. Gatenby $(1965,14)$, one of the founding fathers of ESL, formulated that "what is essential is that the language being studied should be as far as possible the sole medium of communication in any given environment." Since 1965, L2-only pedagogy in ESL teaching has always been the norm (McMillan \& Rivers, 2011).

On the level of policy, the English Only Movement (Wiley \& Lukes 1996) in the U.S. convinced many language school administrators, teacher educators, policy makers and teachers and students to use English as the sole Medium of Instruction (MoI). When the English language became associated with patriotism in the Americanization Movement during the first quarter of the 20th century, English-only became the norm in ESL classes for immigrants with other mother tongues. However, many people now believe that it has gone too far and has become an extreme perspective in ESL teaching, disregarding many important factors influencing students' English learning. Atkinson (1993) argued that it had reached a hegemonic status with regard to the teaching and learning of English as an L2. This "linguistic imperialism" has not left much scope for the development of other languages in multilingual 
communities (Phillipson, 1992, 306). In this regard, Phillipson's (1992) proposed a "Five Tenets", which described and criticized the common assumptions about ESL teaching and learning.

English is best taught monolingually

The ideal teacher of English is a native speaker

The earlier English is taught, the better the results

The more English is taught, the better the results

If other languages are used much, standards of English will drop

The monolingual tenet (tenet one) holds that the only language permitted in the English classroom is English. Many teachers have unconsciously reinforced this approach in actual classroom teaching. The strongest support to monolingualism is to "ban" students' mother tongues completely from the ESL classrooms. Some schools and teachers even devised a penalty system to punish any use of students' mother tongues. In one of the cases, one teacher warned the students that "this is an English-only classroom. If you speak Spanish or Cantonese or Mandarin or Vietnamese or Russian or Farsi, you will pay me 25 cents. I can get rich" (Weinberg 1990). This penalty system assumes that no other language can exist in the ESL classroom, except for English - the target language. Beyond the classroom, similar warnings and regulations were seen and heard constantly from official language policies, teaching syllabuses and teacher training guides as well.

Nevertheless, languge educators and linguists argued against the dominant monolingualism in language classrooms. Paulo Freire (1996), theorist of critical pedagogy, pointed out that the content of the curriculum of adult education is drawn from participants' life experiences and invites reflection on these experiences. Similarly, Rivera $(1988,2)$ argued that education is to empower students to use their mother tongues actively in order to generate their own curriculum and knowledge. In recent education theories, rethinking and designing a curricular architecture using learners' full linguistic repertoires becomes not only feasible, but a logical imperative for successful learning (Levine 2011: 23). Therefore, a monolingual approach for Enlgish language learning should be rejected because it denies students the right to draw on their language resources and strengths by forcing a focus on childlike uses of language and excluding the possibility of critical reflection.

Multilingual pedagogy draws on Vygotsky's $(1978,86)$ sociocultural theory supports the idea that cognitive development is a mediated process driven by social interaction. It is well-known that the transfer of functions from the social domain to the cognitive plane occurs within the zone of proximal development (ZPD). Within the ZPD, scaffolding occurs or that semiotically mediated interactions lead to language learning development. People learn language for social communication. That is to say, codeswitching, or multiple language use in conversation can be especially helpful in situations when the learner needs affordances for learning or simple maintenance of their social position in conversation with the teacher and other learners, or when learners scaffold interactions toward intelligibility and learning. Kim (2008) and Littlewood and Yu (2009) argued that depriving students completely of this support by immersing them in a strange environment, where they feel disoriented and powerless, has been identified as one possible source of de-motivation.

\section{Conclusion}

This paper discussed the complexities and alternations of English in education language policy planning in the United States. By answering the question why English is not the national language of the United States, the study has examined a number of important policy movments in the last century. The United States needs a language that promotes language learning in ways that serve the national interests, and also a good language policy to strengthen opportunities to learn English but should not stop there. English alone is not enough in today's global economy. Monolingualism, for which Americans are justifiably notorious, contributes an economic handicap (Crawford, 2006). As globalization increases, competitors who are proficient in other languages will have an increasing advantage. Americans needs to expand the English Plus policy to produce well-developed skills in many languages to enhance international competitiveness and national security.

Meanwhile, the United States needs a language policy that values the languages of immigrants and indigenous minorities, recognizing them not as a problem but as a resource, rather than attempting to stamp out language diversity with English Only laws. In the long run, the government should conserve and develop multiple language skills to encourage community harmony, foster cultural expression, and meeting the nation's higher needs (Crawford, 2008a, 5). In contrast to treating bilingualism as a nuisance or a threat, it is of tremendous importance to exploit our 
diversity to enrich the lives of individuals and foster the nation's interests, while encouraging ethnic tolerance and safeguarding civil rights (Crawford, 2006). English in the U.S. has a battle to fight on its home ground. As long as the U.S. remains a country committed to receiving immigrants from other countries, there will be a steady influx of speakers of other languages. That whether their descendants will be able to retain their mother tongues while acquiring sufficient English to function well in the U.S. is an open question (Tottie, 2002, 245).

Lastly, ESL teachers need to learn how to "maximize" the use of the target language with adequate knowledge of classroom management skills and thorough understanding of the rationale of popular teaching approaches such as task-based language learning, communicative approach, content and language integrated learning. This stance emphasizes the usefulness of students' mother tongues rather than its harmful and negative functions. However, students' mother tongues are still seen as detrimental and sometimes annoying in ESL classrooms. Additionally, teachers tend to find it professionally problematic to speak students' mother tongues, or technically challing to control multiple language use at the same time, often in a fear of opening the floodgate of students' mother tongues. Future studies should focus on when and how to use students' mother tongue to best achieve the classroom language learning outcomes.

\section{Acknowledgements}

Special thanks will be given to Professor Andy Kirkpatrick from Griffith University for reading the early draft of this article and his insightful comments.

\section{References}

Atkinson, D. (1993). Teaching in the target language: A problem in the current orthodoxy. Language Learning Journal, 8(1), 2-5. http://dx.doi.org/10.1080/09571739385200261

Banks, J. A. (2001). Series foreword. In G. Valdes (Ed.), Learning and not learning English in school: Latino students in American schools (pp. ix-xiii). New York: Teachers College Press.

Butzkamm, W. (2003). We only learn language once. The role of the mother tongue in FL classrooms: Death of a dogma. Language Learning Journal, 28, 29-39. http://dx.doi.org/10.1080/09571730385200181

Cook, V. (2001). Using the first language in the classroom. Canadian Modern Language Review/La Revue canadienne des langues vivantes, 57(3), 402-423. http://dx.doi.org/10.3138/cmlr.57.3.402

Cooper, R. L. (1989). Language planning and social change. Cambridge: Cambridge University Press.

Crawford, J. (2007). No Child Left Behind: A failure for English language learners. Retrieved from http://elladvocates.org/documents/nclb/NCLB_and_ELLs.pdf

Crawford, J. (1991). Bilingual education: History, politics, theory, and practice. Los Angeles, CA: Bilingual Education Services.

Crawford, J. (1992). What's behind Official English? In J. Crawford (Ed.), Language loyalties: a source book on the Official English controversy (pp. 171-177). Chicago: University of Chicago Press.

Crawford, J. (2000). At war with diversity: U.S. language policy in an age of anxiety. Bristol: Multilingual Matters.

Crawford, J. (2006). Official English legislation: bad for civil rights, bad for America's interest, and even bad for English. Retrieved from http://www.elladvocates.org/documents/englishonly/Crawford_Official_English_testimony.pdf

Crawford, J. (2008a). FAQ about official English. Retrieved from http://www.elladvocates.org/documents/englishonly/OfficialEnglishFAQ.pdf

Crawford, J. (2008b). Language legislation in the U.S.A.. Retrieved from http://ourworld.compuserve.com/homepages/jwcrawford/langleg.htm

Crawford, J. (2008c). No Child Left Behind: Misguided approach to school accountability for English language learners. In J. Crawford (Ed.), Advocating for English Learners: selected essays (pp. 128-138). Clevedon: Multilingual Matters Ltd.

Crawford, J., \& MacSwan, J. (2008). Statement on ELLs for Obama transition team. Retrieved from http://www.elladvocates.org/documents/Statement_for_Obama_Transition.pdf 
Cruz, J. (1998). The case against bilingual education. The Atlantic Monthly, 281(5), 28-31.

Dicker, S. J. (1996). Language in America: A pluralist view. Clevedon: Multilingual Matters.

Fillmore, L. W. (2004). Language in education. In E. Finegan, \& J. R. Rickford (Eds.), Language in the USA: Themes for the twenty first century (pp. 339-360). Cambridge: Cambridge University Press.

Fishman, J. A. (1991). Interpolity perspective on the relationships between linguistic heterogeneity, civil strife and per capita gross national product. Applied Linguistics, 1, 5-18.

Freire, P. (1996). Pedagogy of the oppressed. London; New York: Penguin Books.

Gary C. Lawrence Co. (1992). Telephone Survey. Retrieved from http://ourworld.compuserve.com/homepages.JWCRAWFORD/HYTCH6.htm

Gatenby, E. V. (1965). Conditions for success in language learning. In H. B. Allen (Ed.), Teaching English as a Second Language: A Book of Readings (pp. 9-14). New York: McGraw-Hill.

Haugen, E. (1972). The Ecology of language: Essays by Einar Haugen. Stanford, CA: Stanford University Press.

Hawkins, E. (1987). Modern languages in the curriculum. Cambridge: Cambridge University Press.

Heath, S. B. (1992). Why no official Tongue? In J. Crawford (Ed.), Languages loyalties: A source book on the official English Controversy (pp. 20-31). Chicago: University of Chicago Press.

Hispanic Links News Services. (1998). University of California, Los Angeles, Humanities Web. Retrieved from http://www.humnet.ucla.edu/humnet/linguistics/people/grads/macswan/HL3.htm

Kim, S. Y. (2008). Five years of teaching English through English: Responses from teachers and prospects for learners. English Teaching, 63(1), 51-70.

Kirkpatrick, A. (2008). English as the official working language of the Association of Southeast Asian Nations (ASEAN): Features and strategies. English Today, 24(2), 27-34.

Levine, G. (2011). Code choice in the language classroom. Bristol: Multilingual Matters.

Lin, A. M. Y. (2015). Conceptualising the potential role of L1 in CLIL. Language, Culture and Curriculum, 28, 74-89. http://dx.doi.org/10.1080/07908318.2014.1000926

Littlewood, W., \& Yu, B. (2009). First language and target language in the foreign language classroom. Language Teaching, 44(01), 64-77. http://dx.doi.org/10.1017/S0261444809990310

McArthur, T. (2003). Oxford guide to world English. Oxford: Oxford University Press.

McCarty, T. L. (2004). Dangerous difference: A critical-historical analysis of language education policies in the United States. In J. W. Tollfeson, \& A. B. Tsui (Eds.), Medium of instruction policies: Which agenda? Whose agenda? (pp. 71-94). Mahwah, NJ: Lawrence Erlbaum Associates.

McMillan, B. A., \& Rivers, D. J. (2011). The practice of policy: teacher attitudes toward "English only". System, 39, 251-263. http://dx.doi.org/10.1016/j.system.2011.04.011

Miller, J. J. (1998). The unmaking of Americans: How multiculturalism has undermined the assimilation ethic. New York: The Free Press.

Nunan, D. (2003). The impact of English as a global language on dducational policies and practices in the Asia Pacific region. TESOL Quarterly, 37(4), 589-613. http://dx.doi.org/10.2307/3588214

Pennycook, A. (2001). Lessons from colonial language policies. In R. D. Gonalez, \& I. Melis (Eds.), Language ideologies: Critical perspectives on the Official English movement: History, theory, and policy (pp. 198-220). Mahwah, NJ: National Council of Teachers and English and Lawrence Erlbaum Associates.

Phillipson, R. (1992). Linguistic imperialism. Oxford: Oxford University Press.

Phillipson, R. (2003). English-only Europe?: Challenging language policy. Psychology Press.

Porter, R. P. (1996). Forked tongue: the politics of bilingual education. New Brunswick: Transaction Publishers.

Ricento, T., \& Burnaby, B. (1998). Language and politics in the United States and Canada: Myths and realities. Mahwah, NJ: Lawrence Erlbaum Associates.

Rivera, K. (1998). Not “either/or" but "and”: Literacy for non-English speakers. Focus on Basics, 1(3/4), 1-3.

Roosevelt, T. (1992). One flag, one language. In J. Crawford (Ed.), Languages loyalties: A source book on the 
official English Controversy (pp. 84-85). Chicago: University of Chicago Press.

Schlesinger, A. M. (1992). The disuniting of America: Reflections on a multicultural society. New York: W.W. Norton \& Company.

Shin, H. B., \& Bruno, R. (2003). Language use and English-speaking ability. Washington, DC: U.S. Census Bureau.

Tottie, G. (2002). An introduction to American English. Massachusetts: Blackwell Publishers Inc.

Vygotsky, L. S. (1978). Interaction between learning and development In L. S. Vygotsky, M. Cole, V. John-Steiner, S. Scribner, \& E. Souberman (Eds.), Mind in society: The development of higher psychological Processes (pp. 79-91). Cambridge, MA: Harvard Universality Press.

Weinberg, J. (1990). Pennies from He Vinh. TESOL Newsletter, 24(3), 5.

Weistein, B. (1983). Language strategists: redefining political frontiers on the basis of lingual choices. World Politics, 20, 344-364. http://dx.doi.org/10.2307/2009993

Wiley, T. G. (2004). Language planning, language policy, and the English-Only Movement. In E. Finegan, \& J. R. Rickford (Ed.), Language in the USA: themes for the twenty first century (pp. 319-338). Cambridge: Cambridge University Press.

Wiley, T. G., \& Lukes, M. (1996). English-only and standard English ideologies in the US. TESOL Quarterly, 30(3), 511-535. http://dx.doi.org/10.2307/3587696 